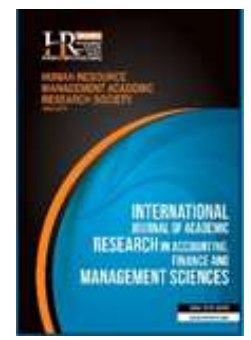

International Journal of Academic Research in Accounting, Finance and Management Sciences

Vol. 9, No.4, October 2019, pp. 269-278

E-ISSN: 2225-8329, P-ISSN: 2308-0337

(C) 2019 HRMARS

www.hrmars.com

To cite this article: Saragih, T.R., Aswar, K. (2019). The Influencing Factors of Taxpayer Compliance: Risk Preferences as $A$ Moderating Variable, International Journal of Academic Research in Accounting, Finance and Management Sciences 9 (4): 269-278

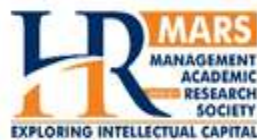

\title{
The Influencing Factors of Taxpayer Compliance: Risk Preferences as a
} Moderating Variable

\author{
Tresia Risda Saragih ${ }^{1}$, Khoirul Aswar ${ }^{2}$ \\ ${ }^{1,2}$ Faculty of Economics and Business, Universitas Pembangunan Nasional Veteran Jakarta, Jl. RS Fatmawati, Pondok \\ Labu, Jakarta, ${ }^{1}$ E-mail: tresiarisda1106@gmail.com, ${ }^{2}$ E-mail: aswar_law@yahoo.com
}

\begin{abstract}
This research was conducted to examine and determine the factors that influence taxpayer compliance with risk preference as a moderating variable. The independent variable used in this study is understanding of taxation regulations, tax sanctions, and tax rates. The population in this study was 1,613,317 taxpayers registered at SAMSAT Bekasi City. Sampling was done using the Accidental Sampling method on taxpayers registered at SAMSAT Bekasi City which produced 99 samples. The data analysis technique used is Structural Equation Modeling (SEM) using the Partial Least Square application with a significance level of $5 \%$. The results of this study indicate that understanding of tax regulations, tax sanctions, and tax rates has a significant effect on the level of compliance of taxpayers, risk preference does not significantly influence the relationship between understanding of tax regulations on tax compliance levels and risk preference has a significant effect on the relationship between tax sanctions with taxpayer compliance level.
\end{abstract}

Key words

Understanding of Tax Regulations, Tax Sanctions, Tax Rates, Risk Preferences, Taxpayer Compliance

Received: 26 Jan $2020 \quad$ (c) The Authors 2019

Revised: $\quad 30$ Jan $2020 \quad$ Published by Human Resource Management Academic Research Society (www.hrmars.com)

Accepted: $\quad 04$ Feb 2020 This article is published under the Creative Commons Attribution (CC BY 4.0) license. Anyone may reproduce, distribute, translate and create derivative works of this article (for both commercial and non-commercial purposes), subject to full attribution to the original publication and authors. The full terms of this license may be seen at: http://creativecommons.org/licences/by/4.0/legalcode

\section{Introduction}

In general, tax is compulsory contributions paid by the people to a country which useful for the benefit of government and society because tax is state revenue that will be used for the construction of public facilities. Therefore, taxes are important for state income. National development is one of the ongoing government activities continuously. State revenue in 2018 amounted to Rp1,942.3 trillion or $102.5 \%$ with the tax ratio reaches $11.5 \%$ of the increased Gross Domestic Product (GDP) by $0.8 \%$ from 2017 (Kemenkeu, 2019). Even so, the acceptance ratio tax in Indonesia is the lowest among the G-20 countries and countries emerging markets. To be equal to developing countries, Indonesia needs to have a tax ratio of $20 \%$ of GDP. To achieve this target the government seeks to reform taxation in various ways, one of which is building tax compliance and awareness. level of compliance Indonesian people in paying taxes are still very low compared to other countries, as a comparison of the tax ratio in Malaysia of $16 \%$, the Philippines 14\%, Thailand 17\%, South Korea 25\%, South Africa 27\%, and Brazil 34\% (Detik Finance, 2018).

One of the local taxes levied by the local government from the people is tax Motorized Vehicles in 2018, the tax target in Bekasi will reach Rp. $928,833,000,000$, but the realization was $35.13 \%$ or Rp. $326,292,255,850$, with a total of 1,459,933 units of motorized vehicles. In April 2018, 546,922 units of vehicles have not been paid annual taxes motorized vehicles or $37.46 \%$ (Tribun, 2018). In January 2019, the number of motorized vehicles was at Bekasi as many as 1,613,317 units, while the number of motorized 
vehicles is as much 620,073 units are still in arrears on motor vehicle tax with the potential for mandatory receivables the tax is estimated to be more than IDR 186,000,000,000. According to research results in the field the reason Bekasi residents are in arrears in tax payments is because lack of awareness of paying taxes and his financial condition (Tempo, 2019).

Based on the above, the researcher wants to conduct a research related to tax compliance. One reason for the low morale of a tax is a tax rate that is too high so it is burdensome for the mandatory tax. In the study of Atawodi and Ojeka (2012) high tax rates is a factor the most important thing that causes noncompliance with taxes. Tax rate motorized vehicles are regulated in Law No. 28 of 2009 article 6, namely for first motor vehicle ownership is at least $1 \%$ (one percent) and the highest of $2 \%$ (two percent). There are a number of studies related to the effect of tax rates on taxpayer compliance such as research conducted by Cahyani and Naniek (2019), Tawas et al. (2016), Helhel and Helhel (2014), Atawodi and Ojeka (2012) where the results of the study stated that Tax rates have a positive effect on taxpayer compliance. Results of the study inversely proportional to the research conducted by Mas'ud et al. (2014) which the results of the study tax rates have a negative effect on taxpayer compliance, and research conducted by Mustofa et al. (2016), Yusro and Kriswanto (2014) which stated that the tax rate is not affect the compliance of taxpayers.

In addition, an understanding of tax regulations is also a factor which affects taxpayer compliance. If taxpayers understand more about taxation regulations, the more taxpayers will understand the sanctions that will be accepted if they neglect their tax obligations (Ananda et al., 2015). There are a number of studies related to understanding regulations taxation of taxpayer compliance which is the result of the research understanding of tax regulations has a positive effect on mandatory compliance taxes (Cahyani and Naniek 2019, Mareti and Dwimulyani 2019, Asrianti, 2018, Utari and Setiawan 2019, Ananda et al. 2015, Adiasa 2013). The results of the study are inversely proportional to research by Syah and Krisidiyawati (2017), Andinata (2015), Mas'ud et al. (2014) in which the understanding of tax regulations has no effect taxpayer compliance.

Another factor that is considered to affect tax compliance is tax sanctions. There are a number of studies related to the effect of tax sanctions on taxpayer compliance conducted by Cahyani and Naniek (2019), Mareti and Dwimulyani (2019), Asrianti (2018), Syah and Krisdiyawati (2017), Setiawan and Meliana (2017), Tawas et al. (2016), Helhel and Helhel (2014), Ardyanto and Utaminingsih (2014) where the results of the study stated that tax sanctions have a positive effect on taxpayer compliance. The results of this study are inversely proportional to that of the study conducted by Rahmawati and Yulianto (2018), Andinata (2015), Pranata et al. (2015) which states that tax sanctions do not affect the tax taxpayer compliance. According to Alabede et al. (2011) things that must be considered in taxpayers making tax payments is a risk that taxpayers must consider before making tax payments. Torgler (2003) conveys that decision a taxpayer can be influenced by his behavior towards the risks faced. Based on the description that has been stated above, the main problems are will be examined as follows:

a) Does understanding of tax regulations affect on taxpayer compliance?

b) Does the tax sanction affect on taxpayer compliance?

c) Does the tax rate affect on taxpayer compliance?

d) Does risk preference affect on taxpayer compliance?

e) Does risk preference can moderate the relationship between understanding of tax regulations with taxpayer compliance?

f) Does risk preference can moderate the relationship between tax sanctions with taxpayer compliance?

\section{Literature review}

\subsection{Prospect theory}

Prospect theory is a theory that explains how one takes decisions in uncertain conditions. Prospect theory was first developed by Daniel Kahneman and Amos Tversky in the early 1980s, where this theory is includes two scientific disciplines namely psychology and economics which is an analysis a person's behavior in making decisions between two choices. Related research uses prospect theory as a theoretical basis for examines taxpayer compliance with risk preferences as moderation, which is Mareti and 
Dwimulyani (2019), Irawati and Sari (2019), Tambun and Witriyanto (2018), Setiawan and Meliana (2017), Ardyanto and Utaminingsih (2014), Adustom (2013), Aryobimo and Cahyonowati (2012), Alabede et al. (2011), and Torgler (2003). The relationship of this research to prospect theory is to explain preferences risks can affect taxpayer compliance. If a taxpayer has high risk, the taxpayer will not necessarily pay the obligation the tax because if the taxpayer has the risk seeking nature though taxpayers have a high risk then it will not affect taxpayers to keep paying taxes, whereas taxpayers who have the risk aversion if taxpayers have low risk, the taxpayers will avoid it tax liability.

\subsection{Theory Planned of Behavior}

Theory of planned behavior is a theory that emphasizes the rationality of human behavior is also in the belief that the target behavior is below control of individual consciousness. According to Ajzen (1991), individual behavior is influenced by individual's intention (behavioral intention) towards that particular behavior. There are three Components in Theory Planned Behavior, include: Behavioral beliefs, individual beliefs will result from a behavior and evaluation of these results (beliefs strength and outcome evaluation), such as taxpayer awareness. In addition, normative beliefs, namely beliefs about the normative expectations of others and motivation to meet these expectations (normative beliefs and motivation to comply), like understanding tax regulations. Next, Control beliefs about the existence of things that support or inhibit that behavior will be displayed (control beliefs), such as tax penalties and tax rates and perceptions about how strong the things that support and hinder the behavior (perceived power). Barriers that may arise when the behavior is displayed can come from within oneself and from the environment.

This theory explains that taxpayers will comply or not in their obligations in the field of taxation by considering the benefits and effects of his actions in paying taxes. In addition the taxpayer will consider the information obtained from outside. Thus, taxpayers will be influenced by certain factors in His actions are control of trust. Research that uses theory of planned behavior as a theoretical basis for examining taxpayer compliance, Widanaputra and Ratnadi (2019) using the independent variable awareness of taxpayers, obligations moral, and environment, Novianti and Dewi (2017) with independent variables which used is tax amnesty, and Nugraheni and Purwanto (2015) with variables independent awareness of taxpayers, tax knowledge and understanding, sanctions tax, the tax authority, the quality of tax services, attributable justice, procedural justice, and interactional justice.

\section{Development of Hypotheses and Research Models}

The development of hypotheses in this study is based on factors that are allegedly having an influence on the level of tax compliance, so that it can formulate as follows:

\subsection{Effects of Understanding of Taxation Regulations on Taxpayer Compliance}

An understanding of taxation is needed so that taxpayers understand, understand, to be able to apply what is contained in the regulations listed. In research Cahyani and Naniek (2019), Mareti and Dwimulyani (2019), Utari and Setiawan (2019), Asrianti (2018), Mustofa (2016), Ananda et al. (2015), dan Adiasa (2013) examine the influence of understanding of regulations taxation of taxpayer compliance. The results of previous studies stated that understanding of tax regulations has a significant effect on taxpayer compliance. Based on the description above, a hypothesis can be formulated as follows:

$\mathrm{H} 1=$ Understanding tax regulations has a significant on rates taxpayer compliance.

\subsection{Effects of Tax Sanctions on Taxpayer Compliance}

Tax sanctions must be given as a form of punishment for taxpayers who are breaking the rules will be a deterrent so as not to repeat it again so creating an increase in tax compliance. In Cahyani and Naniek's research (2019), Mareti and Dwimulyani (2019), Asrianti (2018), Mustofa et al. (2016), Syah and Krisdiyawati (2017), Setiawan and Meliana (2017), Tawas et al. (2016), Helhel and Helhel (2014), Ardyanto and Utaminingsih (2014) tested tax sanctions for taxpayer compliance. The results of previous studies stated that tax sanctions have a significant effect on taxpayer compliance. Based on description above, then the hypothesis can be formulated as follows: 
$\mathrm{H} 2=$ Tax sanction has a significant effect on taxpayer compliance.

\subsection{Effect of Tax Rates on Taxpayer Compliance}

The tax rate is the amount of value that must be paid by taxpayers to country through the fiscus. In the study of Atawodi and Ojeka (2012) stated that exorbitant tax rate cause taxpayer non-compliance. In the research of Cahyani and Naniek (2019), Tawas et al. (2016), Helhel and Helhel (2014), and Atawodi and Ojeka (2012) examine the tax rate on taxpayer compliance. The results of previous studies stated that the tax rate has significant effect taxpayer compliance. Based on the description above, it can be formulated hypothesis as follows:

H3 = Tax rates has a significant effect on taxpayer compliance.

\subsection{Effect of Risk Preference on Taxpayer Compliance}

According to Torgler (2003) Risk preferences can affect a person's decision taxpayers against the risks faced. The risk of being the one considered taxpayers in paying taxes (Alabede et al., 2011). When risk preferences have a strong relationship with taxpayer compliance, then the level of taxpayer compliance will be low. In the research of Dwi et al. (2019) as well Aryobimo and Cahyonowati (2012) risk preferences have a positive effect on taxpayer compliance. On the other hand in the research of Irawati and Sari (2019), Setiawan and Meliana (2017), Adiasa (2013) risk preference has no effect on compliance taxpayer. Based on the description, the hypothesis can be formulated as following:

$\mathrm{H} 4$ = Risk preference has a significant effect on taxpayer compliance.

\subsection{Effects of Risk Preference on Relationships Between Understanding of Tax Regulations with taxpayer compliance}

Risk preference as a moderating variable which means risk preferences can be strengthen or weaken the relationship between understanding of tax regulations with tax compliance. In dealing with risks that are happens every taxpayer must have a decision to face a risk. When the taxpayer has problems in his social life, such as lack information about taxation or changes in policy will affect taxpayer compliance. In the research of Dwi et al. (2019), Utari and Setiawan (2019), Asrianti (2018) Risk preferences can moderated understanding about tax regulations with taxpayer compliance. Therefore, researchers are interested re-test the hypothesis to find empirical evidence so that the hypothesis which was formulated in this research, include:

$\mathrm{H} 5=$ Risk preference has a significant effect on the relationship between understanding of tax regulations with taxpayer compliance.

\subsection{Effects of Risk Preference on the Relationship between Tax Sanctions with taxpayer compliance}

One of the goals of tax sanctions is to create compliance with payments tax. According to Elin and Susi (2019) tax sanctions are a deterrent to compulsory tax does not violate existing rules. When the taxpayer does not pay tax the vehicle will risk being netted in zebra operations carried out by the authorities the police, administrative fines. So with these risks it will affect taxpayer compliance. When taxpayers have jobs that are not still, taxpayers are aware of existing sanctions if they do not comply with existing regulations and will add to the burden because many risks will be faced. This is in line with prospect theory which the risk of financial condition is able to influence tax compliance that will result in tax penalties if you do not pay the tax. In the research Asrianti (2018) risk preferences affect the relationship of tax sanctions with taxpayer compliance. Therefore, researchers are interested re-test the hypothesis to find empirical evidence so that the hypothesis which was formulated in this research, include:

H6 $=$ Risk preference has a significant effect on the relationship between tax sanctions with taxpayer compliance

\section{Methodology of research}

The method in this study used a questionnaire survey to taxpayers registered in SAMSAT Bekasi. A total of 99 questionnaires were returned. The hypothesis in this study was tested using Structural Equation 
Modeling (SEM) by the Smart Partial Least Square (PLS) application. The dependent variable in this study is taxpayer compliance measured using indicators adopted from research conducted by Rahmawati and Yulianto (2018).

The independent variable in this study was to understanding of tax regulations measured using indicators adopted from Adiasa (2013), tax sanctions from Ardyanto and Utaminingsih (2014), and tax rates from Cahyani and Naniek (2019). In addition, the moderating variable in this study is risk preference measured using indicators adopted from Adiasa (2013). This study was measured using a Likert scale with 5 levels ( 1 = Strongly Disagree, 2 = Disagree, $3=$ Neutral, $4=$ Agree, $5=$ Strongly Agree) .

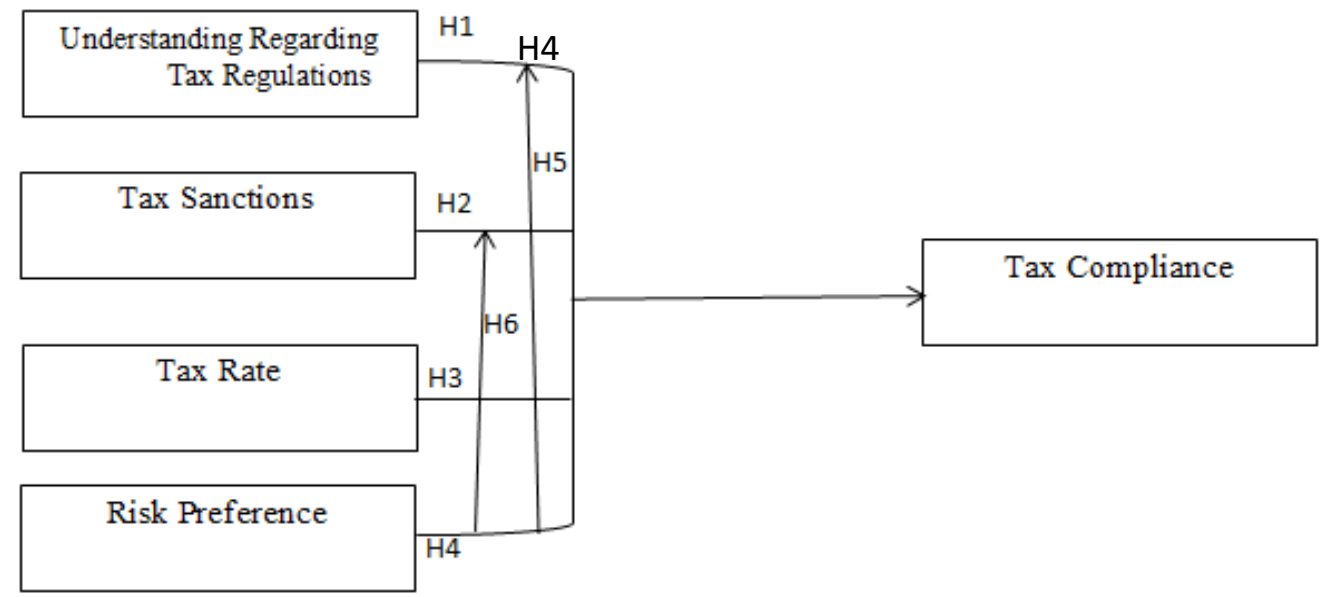

Figure 1. Conceptual Framework

\section{Results and discussions}

Validity and reability tests are done before testing hypothesis. Test the validity by looking at the extracted average variance (AVE) with suggested values above 0.5 and reability test with see the value of Composite Reliability and Cronbach's Alpha. Composite reliability value for all constructs above 0.7 which means all constructs in this study, it is estimated that it meets the criteria and values suggested in Cronbach's Alpha is above 0.6 for all constructs (Ghozali, 2014). Besides that, in assessing a model with PLS will begin by looking at $R$ - Square $\left(R^{2}\right)$ for each dependent latent variable (Ghozali, 2014). Test results validity and Reliability can be seen in the following table:

Table 1. Validity and Reliability Test Results

\begin{tabular}{cccc}
\hline $\mathrm{R}^{2}=0,612$ & \multicolumn{3}{c}{ Cronbach's Alpha } \\
\hline Variabel & AVE & Composite Reliability & 0,743 \\
KP & 0,575 & 0,841 & 0,709 \\
PPP & 0,534 & 0,821 & 0,909 \\
PR & 0,502 & 0,922 & 0,803 \\
SP & 0,631 & 0,872 & 0,607 \\
TP & 0,715 & 0,834 & C
\end{tabular}

In the table above, the lowest AVE value is 0.502 at moderating variable is risk preference. Then it can be concluded that throughout variable is declared valid. Then, the lowest value in the Composite Reliability value is 0.821 for the variable understanding of tax regulations so it can be concluded that all variables in this study have good reliability of each construct and Cronbach's value Alpha for the lowest is 0.607 at the tax rate so it can concluded that all variables in this study had a reliability good for each construct. $\mathrm{R}^{2}$ test results tax compliance is equal to 0.612 thus indicating that the variable is latent independent namely understanding tax regulations, tax sanctions, tax rates, and moderation variables is risk preferences, can explain latent variables dependent: taxpayer compliance of $61.2 \%$ and the remaining $38.8 \%$ explained by other factors outside this research such as socialization taxation, taxpayer awareness, and others. 
Table 2. Results Hypothesis Test Path \& Bootstrapping Algorithm

\begin{tabular}{ccccc}
\hline Hypothesis & Variable & Path Coefficient & T Statistics & P Values \\
\hline H1 & PPP -> KP & 0,206 & 2,230 & 0,026 \\
H2 & SP -> KP & 0,458 & 5,119 & 0,000 \\
H3 & TP -> KP & 0,222 & 2,346 & 0,019 \\
H4 & PR -> KP & $-0,119$ & 1,947 & 0,052 \\
H5 & PR. PPP -> KP & $-0,015$ & 0,157 & 0,875 \\
H6 & PR. SP -> KP & 0,193 & 2,045 & 0,041 \\
\hline
\end{tabular}

The results of testing this hypothesis use the structural equation modeling (SEM) model using smart PLS software version 3.0. Table 2 shows that understanding tax regulations (PPP, $t=2.230$ and $p$-value $=$ $0.026)$, tax penalties (SP, $t=5.119$ and $p$-value $=0,000)$, and tax rates $(T P, t=2,346$ and $p$-value $=0.019)$ affects taxpayer compliance (KP), which means $\mathrm{H} 1, \mathrm{H} 2$, and $\mathrm{H} 3$ are accepted. Meanwhile, risk preference $(\mathrm{PR}, \mathrm{t}=1,947$ and $\mathrm{p}$-value $=0.052)$, which means $\mathrm{H} 4$ is rejected. The risk preference in moderating the understanding of tax regulations (PR. PPP, $t=0.157$ and $p$-value $=0.875$ ) does not affect taxpayer compliance, which means $\mathrm{H} 4$ is rejected. Finally, risk preference in moderating tax sanctions $(P R . S P, t=$ 2.045 and $p$-value $=0.041$ ) affects taxpayer compliance. Understanding tax regulations has a significant effect on taxpayer compliance.

Understanding tax regulations has a significant effect on the level of tax compliance. This shows that the higher the taxpayer understands the tax regulations that have been set; the taxpayer tends to be obedient in paying his obligations. The results of this study are supported by research of Cahyani and Naniek (2019), Elin and Susi (2019), Asrianti (2018), Mustofa et al. (2016), Post et al. (2015), and Adiasa (2013) who state that understanding of regulations taxation has a significant effect on taxpayer compliance. The results of this study are also in accordance with the theory of planned behavior whereby understanding tax regulations as normative beliefs that mean beliefs about the normative expectations of others and motivation to fulfill these expectations (normative beliefs and motivation to comply).

In the relationship of tax sanctions to taxpayer compliance shows that tax sanctions significantly influence tax compliance. This shows that the application of sanctions imposed on violating taxpayers will cause a deterrent effect so as to increase taxpayer compliance. The results of this study are in line with research by Cahyani and Naniek (2019), Elin and Susi (2019), Asrianti (2018), Mustofa et al. (2016), Asrofi and Krisdiyawati (2017), Tawas et al. (2016), Helhel and Ahmed (2018) 2014), and Arif and Nanik (2014) which state that tax sanctions have a significant effect on taxpayer compliance The results of this study are in accordance with the theory of planned behavior where tax sanctions are linked as control beliefs. In this study, tax sanctions support the level of taxpayer compliance, effective and efficient tax sanctions will increase taxpayer compliance in meeting obligations because it can provide a deterrent effect to any noncompliant taxpayers. Implementation of strict sanctions will harm taxpayers so that taxpayers would prefer to carry out their obligations. In addition, the relationship of tax rates to taxpayer compliance shows that tax rates has a significant effect on taxpayer compliance. This shows that the application of tax rates in accordance with established regulations will increase taxpayer compliance. The results of this study were supported by Cahyani and Naniek (2019), Tawas et al. (2016), Helhel and Ahmed (2014), and Atawodi and Ojeka (2012) who stated that tax rates had a significant effect on tax compliance. The results of this study are consistent with the theory of planned behavior whereby the tax rate as a perception of behavioral control.

Variable risk preference for taxpayer compliance shows that risk preference has no significant effect on taxpayer compliance. This shows that the taxpayers in the study sample accept the existing risks so that risk preferences do not affect taxpayer compliance. The results of this study are not in line with the research of Dwi et al. (2019) and Aryobimo and Cahyonowati (2012) risk preferences have a positive effect on taxpayer compliance. On the other hand, in the research of Irawati and Sari (2019), Setiawan and Meliana (2017), Adiasa (2013) risk preferences do not affect tax compliance. This is not in line with the prospect theory that even though the taxpayer has a high risk, it will not affect the taxpayer to continue paying taxes, while the taxpayer who has a risk aversion if the taxpayer has a low risk, the taxpayer will 
actually avoid his tax obligations. Then, the risk preference variable in moderating the relationship of understanding of tax regulations to taxpayer compliance shows that risk preferences cannot moderate the relationship of understanding of tax regulations towards taxpayer compliance with taxpayer compliance. This shows that the taxpayers sampled in this study understand the tax regulations but the existing risk cannot influence a taxpayer's decision to pay his taxes so that the risk preference cannot moderate the relationship of understanding the tax regulations to the level of tax compliance. The results of this study are not in line with the research of Dwi et al. (2019), Utari and Setiawan (2019), and Asrianti (2018). Risk preferences can strengthen the relationship between understanding tax regulations and taxpayer compliance. However, this study is in line with the study of Adiasa (2013) which states that risk preferences cannot moderate the relationship of understanding tax regulations to taxpayer compliance. The results of this study are not in accordance with prospect theory, where taxpayers will make their own decisions in dealing with existing risks. So, risk preference has no effect on the relationship between understanding tax regulations and the level of tax compliance.

Finally, risk preference in moderating the relationship of tax sanctions to taxpayer compliance shows that risk preferences have a significant effect in moderating the relationship of tax sanctions to taxpayer compliance with taxpayer compliance. This shows that taxpayers who have a high risk will affect the relationship of tax sanctions to the level of tax compliance. The public will comply with the regulations if there are sanctions that are applied because sanctions as a regulatory tool so that taxpayers become more orderly because if they violate the rules set then the risk of being sanctioned will be higher. The results of this study are in line with research by Asrianti (2018) which states that risk preference influences the relationship of tax sanctions with taxpayer compliance. The results of this study are in accordance with prospect theory, where taxpayers will make their own decisions in dealing with existing risks depending on the perspective of the taxpayer to see whether the risk preferences will affect positive or negative.

\section{Conclusions}

This research begins with the problem of taxpayer compliance in Indonesia which is still low and requires improvements to taxpayer compliance. Problems with taxpayer compliance also occur with motor vehicle tax at SAMSAT Bekasi. This study aims to examine and determine the factors that influence taxpayer compliance with risk preference as a moderating variable. The results of this study indicate that understanding of tax regulations, tax sanctions, and tax rates has a significant effect on tax compliance. Meanwhile, risk preference has no effect on taxpayer compliance. Then, risk preference has no effect on the relationship between understanding tax regulations and taxpayer compliance. However, risk preference influences the relationship of tax sanctions with taxpayer compliance. This study has a limitation that this study only uses taxpayer research objects that is registered in SAMSAT Bekasi and cannot be generalized because of the limited time and busyness of taxpayers. In addition, the majority of the sample in this study came from respondents with a senior high school education or less. Meanwhile, the sample with master degree (S2) or doctoral degree (S3) is very small.

Suggestions for this research for SAMSAT Bekasi are expected to be more active in providing information to the whole community through tax socialization to improve tax knowledge and understanding both directly and through the mass media regarding the importance of paying taxes on time, increasing supervision with zebra operations, and improving services to minimize the existence of brokers. Then, for further research it is expected to be able to add other variables such as awareness of taxpayers, taxation socialization, service quality of focus and use the taxation understanding variable as a moderating variable and expand the object of research not only to one SAMSAT but to all SAMSAT in the Bekasi area so that research can be used universally

\section{References}

1. Adinata, M.C. (2015). Analisis faktor-faktor yang mempengaruhi Kepatuhan wajib pajak orang pribadi dalam membayar pajak (Studi kasus pada kantor pelayanan pajak pratama rungkut di Surabaya), Calyptra: Jurnal IImiah Mahasiswa Universitas Surabaya, 4(2), 1-5. 
2. Adiasa, N. (2013). Pengaruh pemahaman peraturan pajak terhadap kepatuhan wajib pajakdengan moderating preferensi risiko, Accounting Analysis Journal, 2(3), 345-352.

3. Adi, W. (2019). Tunggakan kendaraan bermotor di Kota Bekasi. Diakses 12 September 2019, dari https://metro.tempo.co/read/1177976/kota-bekasi-disesaki-16-juta-kendaraan-bermotor-ini-dampaknya

4. Ajezen, I. (2005). Attitudes, personality, and behavior second edition. England: Open University Press.

5. Ajezen, I. (1991). The theory of planned behavior, organizational behavior and human decision processes, 50(2), 179-211.

6. Ajezen, I., \& Fishbein, M. (1975). Belief attitude, intention and behaviour: an introduction to theory and research. California: Addison-Wesley.

7. Alabede, J.O., Ariffin, Z.Z., \& Idris, K.M. (2011). Individual taxpayers' attitude and compliance behaviour in Nigeria: the moderating role of financial condition and risk preference, Journal of Accounting and Taxation, 3(5), 91-104.

8. Ananda, P.R.D., Kumadji, S., \& Husaini, A. (2015). Pengaruh sosialisasi perpajakan, tarif pajak, dan pemahaman perpajakan terhadap kepatuhan wajib pajak (Studi pada UMKM yang terdaftar sebagai wajib pajak di kantor pelayanan pajak pratama Batu), Jurnal Perpajakan (JEJAK), 6(2), 1-9.

9. Ardyanto, A.A., \& Utaminingsoh, N.S. (2014). Pengaruh sanksi pajak dan pelayanan aparat pajak terhadap kepatuhan wajib pajak dengan preferensi risiko sebagai variabel moderasi, Accounting Analysis Journal, 3(2), 220-229.

10.Aryobimo, P.T., \& Cahyonowati, N. (2012). Pengaruh persepsi wajib tentang kualitas pelayanan fiskus terhadap kepatuhan wajib pajak dengan kondisi keuangan dan preferensi risiko sebagai variabel moderating, Diponegoro Journal-Of-Accounting,-3(2),1-1.

11.Asrianti. (2018). Pengaruh pemahaman dan sanksi perpajakan terhadap kepatuhan wajib pajak dengan preferensi risiko seebagai variabel moderasi (Studi pada KPP Pratama Makassar Selatan). Publikasi Program Sarjana Akuntansi, Universitas Islam Negeri Alauddin Makassar.

12.Atawodi, O.W., \& Ojeka, S.A. (2012). Factors that affect tax compliance among small and medium enterprises (SMEs) in North Central Nigeria, International Journal of Business and Management, 7(12), 8796.

13.Cahyani, L.P.G., \& Noviari. N. (2019). Pengaruh tarif pajak, pemahaman perpajakan, dan sanksi perpajakan terhadap kepatuhan wajib pajak UMKM, E- Jurnal Akuntansi Universitas Udayana, 26(3), 18851991.

14.Cooper, D. R., dan Emory, C.W. (1996). Business research methods. Jakarta: Erlangga.

15.Dwi, Y., Paramita, P.D., \& Prananditya, A. (2018). Pegaruh pemahaman peraturan perpajakan dan kesadaran wajib pajak terhadap kepatuhan wajib pajak dengan preferensi risiko sebagai variabel moderating. Journal of Accounting, 1-10.

16. Hendra, K. (2018). Tingkat kepatuhan pajak masyarakat Indonesia masih rendah. Diakses 9 September 2019, dari https://finance.detik.com/berita-ekonomi-bisnis/d-4214299/tingkat-kepatuhanpajak-masyarakat-ri-masih-rendah.

17.Irawati, W., \& Sari, A.K. (2019). Pengaruh persepsi wajib pajak dan preferensi risiko terhadap kepatuhan wajib pajak. Jurnal Akuntansi Barelang, 3(2), 104-114.

18.Jatmiko, N.A. (2006). Pengaruh sikap wajib pajak pada pelaksanaan sanksi denda, pelayanan fiskus dan kesadaran perpajakan terhadap kepatuhan wajib pajak: Studi empiris wajib pajak orang pribadi di Kota Semarang. Program Pasca Sarjana Magister Sains Akuntansi, Universitas Diponegoro.

19.Kementrian, K. (2019). Ini capaian apbn 2018. Diakses 9 September 2019, dari https://www.kemenkeu.go.id/publikasi/berita/ini-capaian-apbn-2018/.

20.Kementerian, K. (2016). Alasan utama rasio perpajakan rendah. Diakses 12-September2019,darihttps://www.kemenkeu.go.id/publikasi/berita-menkeu-nilai-tingkat-kepatuhan-wajib-pajak-indonesiamasih-rendah/.

21.Khneman, D., \& Smith, V. (1979). Prospect theory: an analysis of decision under risk. econometrica, 263-291. 
22.Mareti. E.D., \& Dwimulyani, S. (2019). Pengaruh pemahaman peraturan perpajakan, kualita spelayanan fiskus, sanksi perpajakan, dan tax amnesty terhadap kepatuhan wajib pajak dengan preferensi risiko sebagai variabel moderasi, Prosiding Seminar Nasional Pakar ke 2, 1-16.

23.Mas'ud, A., Aliyu, A.A., \& Gambo, E.J. (2014). Tax rate and tax compliance in Africa,European Journal of Accounting Auditing and Finance Research, 2(3), 22-30.

24.Mustofa, F.A., Kertahdi, \&, R., M.M. (2016). Pengaruh pemahaman peraturan perpajakan, tarif pajak, dan asas keadilan terhadap kepatuhan wajib pajak (Studi pada wajib pajak usaha mikro kecil dan menengah yang berada di wilayah kerja kantor pelayanan pajak pratama Batu setelah diberlakukannya Peraturan Pemerintah Nomor 46 Tahun 2013), Jurnal Perpajakan (JEJAK), 8 (1), 1-7.

25.Novianti, A. F., \& Dewi, N. H. U. (2017). An investigation of the theory of Planned behavior and the Role of tax amnesty in tax compliance, The Indonesian Accounting Review, 7(1), 79-94.

26.Nugraheni, A. D., \& Purwanto, A. (2015). Faktor-faktor yang mempengaruhi kepatuhan wajib pajak orang pribadi (Studi empiris pada wajib pajak di Kota Magelang), Diponegoro Journal Of Accounting, 4(3), 1-14.

27.0ji Saeroji. Menakar kadar kepatuhan wajib pajak. Diakses 12 September 2019, darihttps://www.pajak.go.id/id/artikel/menakar-kadar-kepatuhan-wajib pajak.

28.Pajak.go.id. Pengertian tax ratio. Diakses 9 september 2019, dari https://www.pajak.go.id/id/ artikel/memperbaiki-kinerja-tax-ratio-sebuah-pendekatan-makro.

29.Pranata, T. A., Hamdi, M., \& Herawati. (2015). Pengaruh kesadaran wajib pajak, sanksi denda pajak, dan kualitas pelayanan pajak terhadap kepatuhan wajib pajak dalam membayar pajak kendaraan bermotor di Kota Bukittinggi, Jurnal Universitas Bung Hatta, 2-15.

30.Rahmawati, R., \& Yulianto, A. (2018). Analysis of the factors affecting individual taxpayers compliance, Accounting Analysis Journal, 7(1), 17-24.

31.Setiawan, A. B., \& Meliana, S. (2017). Analisis kepatuhan wajib pajak hotel berdasarkan pemeriksaan pajak, sanksi perpajakan, kondisi keuangan, dan preferensi risiko pada hotel-hotel yang terdaftar di BAPPENDA Kabupaten Bogor. Jurnal Akunida, 3(2), 13-26.

32.Syah, A. L. N., \& Krisdiyawati. (2017). Analisis faktor-faktor yang memepengaruhi kepatuhan wajib pajak dalam membayar pajak kendaraan bermotor (Studi empiris pada kantor UPPD/ SAMSAT Brebes), Jurnal AKSI (Akuntansi dan Sistem Informasi), 2(1), 65-77.

33.Tambun, S., \& Witriyanto, E. (2016). Pengaruh kesadaran wajib pajak dan penerapan e-system terhadap tingkat kepatuhan wajib pajak dengan preferensi resiko sebagai variabel moderating (Studi empiris kepada wajib pajak di komplek perumahan sunter agung Jakarta Utara), Media Akuntansi Perpajakan, 1(2), 86-94.

34.Tawas, V. B. J., Poputra, A. T., \& Lambey, R. (2016). Pengaruh sosialisasi perpajakan, tarif pajak, dan sanksi perpajakan terhadap kepatuhan pelaporan SPT tahunan wajib pajak orang pribadi (Studi kasus pada KPP pratama Bitung), Jurnal EMBA, 4(4), 912- 921.

35.Torgler, B. (2003). Tax morale: theory and analysis of tax compliance. Unpublished doctoral dissertion, University of Zurich, Switzerland.

36. Undang-Undang Republik Indonesia Nomor 28 tahun 2009 Tentang Pajak Daerah dan Retribusi Daerah.

37.Utari, P. D. A., \& Setiawan, P. E. (2019). Pengaruh pemahaman peraturan perpajakan terhadap kepatuhan WPOP dengan preferensi risiko sebagai variabel pemoderasi. E-Jurnal Akuntansi, 28(1), 109-131.

38. Widanaputra, A.A.G.P., Ratnadi, N.M.D., \& Putra, I.N.W.A. (2019). Internal and external factors affecting taxpayer compliance of tax amnesty participants, International Journal of Economics, Commerce and Management. VII(4), 314-331.

39.Yesim, H., \& Yesim, A. (2014). Factors affecting tax attitudes and tax compliance: a survey study in Yemen. European Journal of Business and Management, 6(22), 48-58.

40.Yusro, H. W., \& Kiswanto. (2013). Pengaruh tarif pajak, mekanisme pembayaran pajak dan kesadaran membayar pajak terhadap kepatuhan wajib pajak UMKM di Kabupaten Jepara, Accounting Analysis Journal, 3(4), 429-436. 
41.Bachtiar, Y. (2018). Target pendpatan pajak kendaraan bermotor Kota Bekasi. Diakses 12 September 2019, dari https://jakarta.tribunnews.com/2018/05/07/samsat-targetkan-rp-928-miliar pendapatan-pajak-kendaraan-bermotor-kota-bekasi. 